\title{
18-8系ステンレス鋼の熱損傷による高温特性の変化*
}

\author{
泉 久司** 井門靖博*** 川崎 正****
}

\section{Changes in Mechanical Properties at Elevated Temperatures Caused \\ by Thermal Damage of Austenitic Stainless Steels}

by

\author{
Hisashi Izumi, Yasuhiro Ido \\ (Himeji Institute of Technology, Himeji)
}

and Tadashi KAwAsAkI

(Faculty of Engineering, Tohoku University, Sendai)

This experiment concerning the changes in mechanical strength at the room and elevated temperatures showed that after inflicting thermal damage, that was, the repeated heating and cooling rapidly on the austenitic stainless steels, the thermal cycles did not always weaken the strength of the materials.

The following results were obtained :

(1) By the damage caused by rapid heating and cooling, what is called "strain enhanced precipitation" occurs with increase of hardness due to the slip for thermal stress. The influence of this damage is more remarkable on the bending fatigue characteristics than on the tensile.

(2) When the accumulative thermal damage is moderate, its strength breeds a negative damage and gains at the room and at the high temperature. When it exceeds a certain value, however, the strength drops due to the growth of precipitation particles. Their effect on the strength is more remarkable at the high temperature than at the room temperature.

(3) The precipitation caused by the thermal damage is different in nature from that of ordinary heating, fine precipitation particles occurring within each grain itself, and increasing their resistance to the dislocation movement. However, the cracks due to the damage become the source of fatigue cracks.

(4) The thermal resistance to the repetition of rapid heating and cooling is greater in the type 304 stainless steel than in the types 321 and 347.

(Received Jun. 4, 1964)

\section{1 緒言}

18-8系ステンレス鋼は耐熱材料として，かなり苛酷 な熱条件のもとで使用されるととがある、との鋼種は 熱衝撃に対するき裂の感受性が他の実用合金に比べて 非常に小さいが，加熱が繰り返されると著しい組織 変化を伴って強度およびその他の諸性質にも顕著な影 響を及ぼす。このような熱損傷を受けた場合，機械的 強度に特異な影響を与えるであろうととが予期される。 急熱急冷の繰り返しによる熱損傷を受けた18-8系ス テンレス鋼の常温ならびに高温における機械的強度の 変化を調べ，組織との関連性について検討した。

\footnotetext{
* 原稿受理 昭和 39 年 6 月 4 日

** 正会員 姫路工業大学 姫路市伊伝居

*** 姫路工業大学 姫路市伊伝居

**** 正会員 東北大学工学部 仙台市桜小路
}

昭和 39 年 9 月

\section{2 試料および実験方法}

用いた試料はTable I 亿示す化学成分の AISI 304鋼

Tabel I. Chemical composition (\%).

\begin{tabular}{|c|c|c|c|c|c|c|c|c|c|}
\hline 11 & C & $S_{1}$ & $\mathrm{Mn}$ & $P$ & S & $\mathrm{N}_{1}$ & $\mathrm{Cr}$ & $\Gamma_{1} \mid$ & $\mathrm{Nb}+\mathrm{Ta}$ \\
\hline $304 \mathrm{~T} \backslash \mathrm{pe}$ & 0.06 & 0.78 & 1.32 & $\begin{array}{ll}0 & 034\end{array}$ & 0.008 & 9.61 & 18.60 & - & - \\
\hline 321Type & 0.038 & 80.70 & 1.46 & 0.018 & 0.009 & 10.47 & 18.250 & 0.31 & - \\
\hline 347Туре & 0.063 & $\begin{array}{lll}3 & 0 & 50\end{array}$ & 1.38 & 0.022 & 0.010 & 11.18 & 17.93 & - & 0.79 \\
\hline
\end{tabular}

で，比較のため321ならびに347鋼をあわせて使用した， いずれも大気溶解後, 直径 $16 \mathrm{~mm}$ 亿熱間圧延し, 1050 ${ }^{\circ} \mathrm{C}, 1 \mathrm{hr}$ 加熱してから水冷によった溶体化処理材であ るととれをFig. 1 亿示すように, 平行部の直径 $8 \mathrm{~mm}$ (高温引張用の一部には $7 \mathrm{~mm}$ を使用した)の $1 \sim 3$ 号 の各試験片に機械仕上げしたままのものを標準試料と 


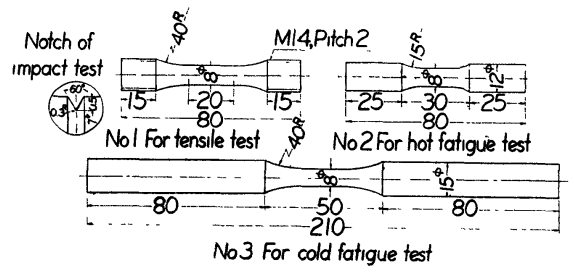

Fig. 1. Size of test pieces.

した.

試料には，真空管式高周波誘導加熱装置を用いて急 熱急冷の繰り返しによって熱損傷を与えた。すすおち 内径 $20 \mathrm{~mm}$ の加熱コイル内に試料を無拘束状態に保持 し，回転させながら自動制御によって加熱冷却サイク ルを連続的に行なった，加熱条件はいずれの場合にも， 陽極電圧 $8 \mathrm{KV}$., 格子電流 $260 \mathrm{~mA}$ ，と一定にし，1 サ

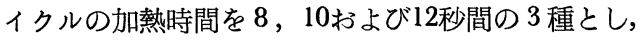
噴水により10秒間で泠却した．とのときの加熱時間と 温度との関係は熱電対で測定した結果Fig. 2 のようで ある。 しかし, 温度上昇速度が速いので正確な温度測 定が困難なため，試料の最高温度は加熱時間で表わす ととにした。

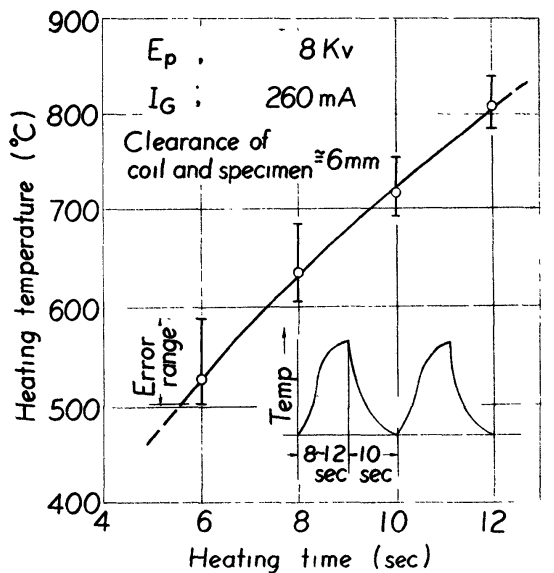

Fig. 2. Temperature character for high frequency induction heating.

以上の方法による同一温度振幅の熱サイクルを 1 〜 500 回繰り返して所定の加熱を加光て試料を 熱損傷材 と呼ぶことにする．損傷材の常温および $650^{\circ} \mathrm{C}$ を心 した高温における引張強度, 疲労強度およびかたさな ぞ材料力学的挙動の変化について実験し, 熱損傷が強 度に及ぼす影響を検討した。疲労試験には $3400 \mathrm{rpm}$ の高温用小野式回転曲げ疲労試験機，かたさ変化には 微小硬度計を使用した，高温試験はすべて所定温度に 到達後, $1 \mathrm{hr}$ 保持してから負荷を開始した。疲労試験 では，常温わよび高温とも $10^{7}$ 回以上の繰返数で破断 しない最高応力をその温度における耐久限とした。ま
た，熱損傷材の機械的試験の前後における組織変化の 観察に対しては 3 酸化クロム水溶液を電解液とした電 解窝食による光学顕微鏡ならびに 2 段レプリカ法によ る電子顕微鏡で検鏡して強度と組織変化の関連性を検 封した。

\section{3 実験結果ならびに考察}

\section{3 - 1 引張特性}

Table II は 304 鋼に対し，加熱時間 8 および12秒と し，熱サイクル（以下 $n$ で表わす）を 5 ～500回繰り 返した熱損傷材の常温における引張試験の結果を示し たものである．すなわち損傷材の耐力（荷重一伸び曲 線の直線部からはずれる点の応力）は，一般的に溶体 化処理材よりも高くなる傾向である。引張強度は 8 秒 加熱材では $n=200$ 回， 12 秒加熱のときは $n=50$ 回の試 料で強度が最高となり，しかも伸びの大きくなる興味 ある結果が得られた。

Table II. Changes in tensile properties of various thermal damages at room temperature.

\begin{tabular}{c|c|c|c|c|c|c}
\hline $\begin{array}{c}\text { Heating } \\
\text { tıme }\end{array}$ & $\begin{array}{c}\text { Thermal } \\
\text { cycles }\end{array}$ & $\begin{array}{c}\text { Proof } \\
\text { stress } \\
\left(\mathrm{kg} / \mathrm{mm}^{2}\right)\end{array}$ & $\begin{array}{c}\text { Tensle } \\
\text { strength } \\
\left(\mathrm{kg} / \mathrm{mm}^{2}\right)\end{array}$ & $\begin{array}{c}\text { Flongation } \\
(\%)\end{array}$ & $\begin{array}{c}\text { Hardness } \\
\text { DPN }\end{array}$ \\
\hline- & - & 27.5 & 66.4 & 71.5 & 178 \\
\hline \multirow{2}{*}{8} & 50 & 28.6 & 61.8 & 73.0 & 218 \\
& 100 & 31.7 & 64.6 & 76.5 & 225 \\
sec & 200 & 30.7 & 67.1 & 60.5 & 228 \\
& 500 & 30.3 & 64.3 & 58.0 & 238 \\
\hline \multirow{3}{*}{12} & 5 & 29.9 & 59.8 & 67.4 & 203 \\
& 10 & 30.5 & 59.9 & 72.0 & 208 \\
\multirow{2}{*}{ sec } & 50 & 34.4 & 65.2 & 74.6 & 210 \\
& 100 & 31.0 & 62.3 & 67.8 & 198 \\
\hline
\end{tabular}

そこで，熱損傷後の常温強度が最高を示した 8 秒， 200回加熱による損傷材 (とのような損傷を負損傷と呼 ぶことにする) を常温 $800^{\circ} \mathrm{C}$ 各温度で高温引張試験 の結果がFig. 3 である．鎖線は $650^{\circ} \mathrm{C} \times 100 \mathrm{hr}$ 加熱によ る析出処理材, 点線は溶体化処理材の変化で, 比較の ために示したものである．熱損傷材の $700^{\circ} \mathrm{C}$ までの高 温引張強度は溶体化処理材と著しい変化はないが，損 傷材のほうがわずかに弱く，常温強度の変化と逆の傾 向が認められる。しかし，高温耐力は図のように，溶 体化処理材に比べてわずかに高くなるが，析出処理材 に比較すると，かなり低いようである。とのように試 験した全温度範囲にわたって損傷材の高温耐力は上昇 し，負損傷を示す。これは厳しい熱サイクルのために 起こるすべりにより，いわゆる strain enhanced precipitation（ひずみ加速析出）が起こって変形抵抗が 増加したためであろう。また伸びの変化は非常に不揃 


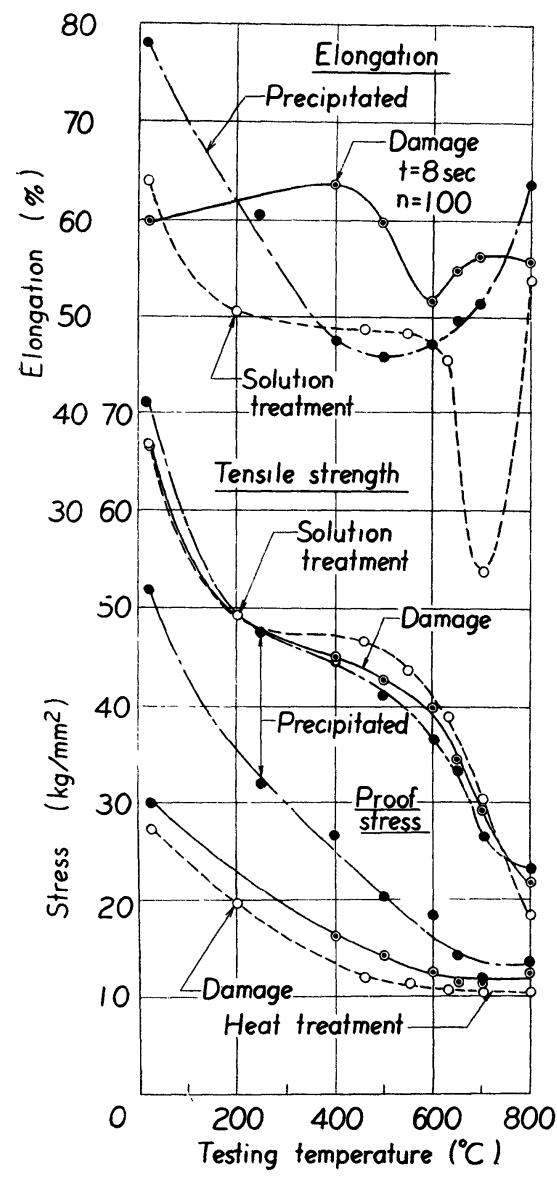

Fig. 3. Tensile properties for thermal damaged specimens of type 304 at elevated temperatures.

いである. しかし，伸びの最小值を示す試験温度は罢 積加熱の大きいほど，低温側に移動し，常温において 最大伸びか現われる傾向を示した。

Fig. 4 (a) (b) は301 鋼熱損傷材の高温引張中に得ら れた荷重一伸び曲線の例である、図のように 8 秒 200 回の損傷材では約 $500 \sim 650^{\circ} \mathrm{C} の$ 温度範国において明ら かな鋸歯状不連続現象か現われ，乙れ以外の温度では 滑らかな曲線となる。乙れは Portevin-Le Chatalier 効果として知られている現象と同じもので，筆者らは オーステナイト系ステンレス鋼にも認められるととを 報告したが，熱損傷材でも完全に消隇しないととがわ かった．Fig. 4 (b)は試験温度を $650^{\circ} \mathrm{C} と し ，$ 累積加熱 が高温引張特性に及ぼす影響について調べた一例であ る.すなわち $650^{\circ} \mathrm{C}$ すおける引張強度は 12 秒，100回の 熱損傷材が最も高く，溶体化処理材に対して約 $34 \%$ 増 加し, 常温強度の場合と異なった変化を示す。また， 耐力は Fig. 3 と同様の傾向で，ほほ累積損傷に比例し

\#1最高加熱温度 (加熱時間) と加熱燥返数の積を累積加熱と定義する.

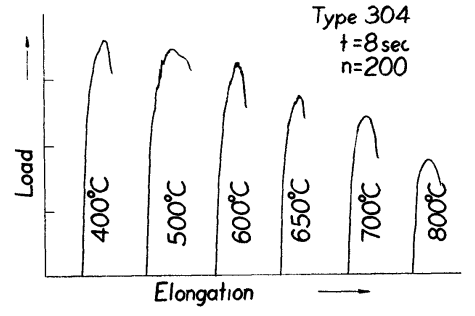

Fig. 4 (a). Load-elongation curves for constant thermal damaged specimens at elevated temperature.

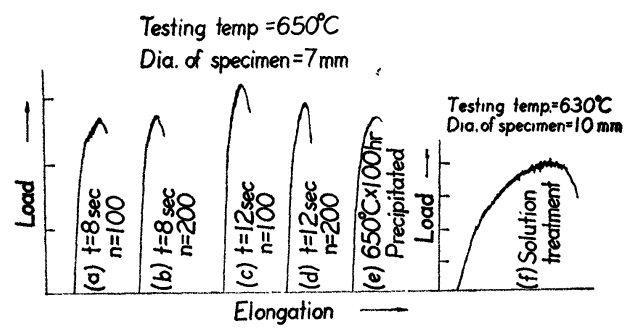

Fig. 4 (b). Load-elongation curves for various themal damaged specimens at $650^{\circ} \mathrm{C}$.

て高い值となる。乙れらの荷重一伸び曲線を注意深く 観察すると，累積損傷の著しいと思われる試料ほど鋸 䨑状の波が小さく現われる傾向が認められる，ステン レス鋼の鋸歯状不連続現象の主因は，高温試験中に生 ずる Strain induced precipitation に基づくもので ある. したがって累積加熱によって析出が促進され， 溶質原子が消費されるとともに不連続現象が現われに くくなる、とれらの結果からステンレス鋼の高温特性 は溶質原子の濃度および分布に密接な関係を有するも のと考光てよからう。

\section{$3 \cdot 2$ 疲労特性}

ステンレス鋼の熱損傷材，ととに急熱急冷の繰り返 しを受けた場合，その損傷条件によって，その後の引 張特性とか後述するかたさの変化に微妙な影響を及ほ すととがわかったので，常温および $650^{\circ} \mathrm{C}$ における疲 労強度に与える効果についても実験した。 その $S-N$ 曲 線をFig. 5 に示す。常温疲労試験にはFig. 1 の 3 号試 験片を用い，熱損傷はすべて 8 秒間加熱で与え，熱サ イクル数 $n$ をパラメータとして表わした. この $S-N$ 曲 線は $n$ の多いほど， 2 本の直線で表現するととは無理 のようで，図のように曲線を用いて表わした，損傷材 の耐久限は一旦， $n$ とともに高くなり，かなり増加さ れる。

たとえば 8 秒，200回の損傷材の耐久限は溶体化処 理材より約 $27 \%$ も高くなる。乙の耐久限増加率は引張 特性の増加率に比較して著しく大で, 耐力と同様に負 損傷を与え，強化されるととがわかる。しかし，さら 


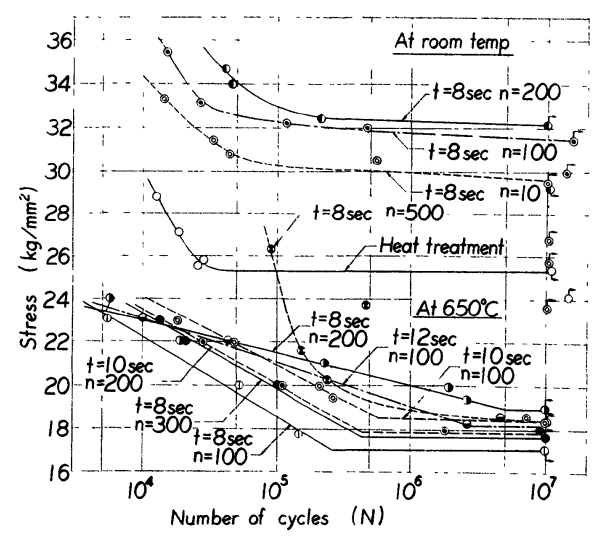

Fig. 5. $S-N$ curves for various thermal damaged materials at room temperature. and $650^{\circ} \mathrm{C}$.
に熱損傷を追加した $n=500$ 回の試料では，試料表面 の酸化が進行して肌荒れが増す. 加わうるにヒートチ エッキングあるいはクレーズクラッキングと呼ばれて いる比較的浅い巨視的き裂が多数発生して有効断面積 が減少するとともに切欠きの影響か現われて耐久限は 急激に低下する。乙の低下率は約 $28 \%$ も達する。

Table III は304鋼の 8 秒加熱による熱損傷材の常温 における機械的性質と熱サイクル数 $n$ との関係で，括 弧内はいずれも溶体化処理材を基準にした場合の増减 率である。一例を挙げると $n=200$ 回では表面かたさ は約28\%増加し，耐久限約27\%とほぼ同じ割合で高く なるが，引張強度はわずか約 $1 \%$ 上昇にすぎないこ とがわかる。一般に 304 鋼の常温での耐久限は耐力よ りも低いが，熱損傷によって耐力は上昇するため，両 者はほぼ等しくなる、また，耐久比はオーステナイト

Table III. Changes in mechanical properties caused by various thermal damages at room temperature.

\begin{tabular}{|c|c|c|c|c|c|c|}
\hline $\begin{array}{l}\text { Thermal } \\
\text { cycles }\end{array}$ & $\begin{array}{l}\text { Proof stress } \\
\sigma_{0 \cdot 2},\left(\mathrm{~kg} / \mathrm{mm}^{2}\right)\end{array}$ & $\begin{array}{c}\text { Tensile strength } \\
\sigma_{\mathrm{B}},\left(\mathrm{kg} / \mathrm{mm}^{2}\right)\end{array}$ & $\begin{array}{c}\text { Endurance limit } \\
\sigma_{\mathrm{wo}},\left(\mathrm{kg} / \mathrm{mm}^{2}\right)\end{array}$ & $\sigma_{\mathrm{WO}} / \sigma_{02}$ & $\sigma_{\mathrm{Wo}} / \sigma_{\mathrm{B}}$ & $\begin{array}{l}\text { Vickers hardness } \\
\text { DPN. }\end{array}$ \\
\hline 0 & 27.5 & 66.4 & 26.4 & 0.91 & 0.38 & 178 \\
\hline 10 & $\begin{array}{c}31.1 \\
(13.1)\end{array}$ & $\begin{array}{r}62.5 \\
(-5.9)\end{array}$ & $\begin{array}{c}29.5 \\
(16.1)\end{array}$ & $\begin{array}{l}0.95 \\
(4.4)\end{array}$ & $\begin{array}{c}0.47 \\
(23.7)\end{array}$ & $\begin{array}{c}226 \\
(27.0)\end{array}$ \\
\hline 100 & $\begin{array}{c}31.7 \\
(15.3)\end{array}$ & $\begin{array}{r}64.6 \\
(-2.7)\end{array}$ & $\begin{array}{c}31.5 \\
(24.0)\end{array}$ & $\begin{array}{l}0.99 \\
(8.8)\end{array}$ & $\begin{array}{c}0.49 \\
(28.6)\end{array}$ & $\begin{array}{c}225 \\
(26.4)\end{array}$ \\
\hline 200 & $\begin{array}{r}30.7 \\
(11.6) \\
\end{array}$ & $\begin{array}{l}67.1 \\
(1.1)\end{array}$ & $\begin{array}{c}32.3 \\
(27.2)\end{array}$ & $\begin{array}{c}1.05 \\
(15.4)\end{array}$ & $\begin{array}{c}0.49 \\
(26.3)\end{array}$ & $\begin{array}{c}228 \\
(28.1)\end{array}$ \\
\hline 500 & $\begin{array}{c}30.3 \\
(10.2)\end{array}$ & $\begin{array}{r}64.3 \\
(-2.8)\end{array}$ & $\begin{array}{c}18.3 \\
(-28.0)\end{array}$ & $\begin{array}{c}0.60 \\
(-34.1)\end{array}$ & $\begin{array}{c}0.28 \\
(-26.3)\end{array}$ & $\begin{array}{c}238 \\
(33.7)\end{array}$ \\
\hline
\end{tabular}

The figures in parenthesis show increased or decreased parcentage.

組織をもつ合金の平均值より大きくなり，疲労強度の 増加が目立つ変化を示す。

一方加熱時間および $n$ を変えた熱損傷材の $650^{\circ} \mathrm{C} て ゙$ の高温疲労試験にはFig. 1 の 2 号試験片を用いて行な

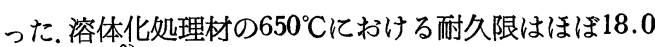
$\mathrm{kg} / \mathrm{mm}^{2}$ で, 実験範囲内の累積加熱では熱損傷による 耐久限の著しい変化はほとんどなく，常温試験に比べ て強度変化率はきわめて少ない. また, $650^{\circ} \mathrm{C} て ゙ の ~ S-N$ 曲線は高温試験中の Strain enhanced precipitation による強化で，時効性合金々同様に 2 本の直線で表わ したほうが適切で，溶体化処理材の高温瘦労と同様に ほぼ一定の耐久限が存在する。しかし，8秒，200回 あるいは 10 秒 100 回などの損傷材は，わずかながら耐 久限が高くなる傾向である。ささに累積加熱を追加し て損傷を増せば酎久限は低下し始め，8 秒，300回の 損傷材は溶体化処理材より低くなる，負損傷材の高温 での $S-N$ 曲線の一つの特徽は耐久限の上昇が比較的 少ないにもかかわらず，疲労寿命の伸びが比較的に大
きいことである。

Fig. 6 (a)は $650{ }^{\circ} \mathrm{C}$ で応力一定の疲労寿命試験から疲 労強度に及ぼす熱損傷の影響について検討した結果で

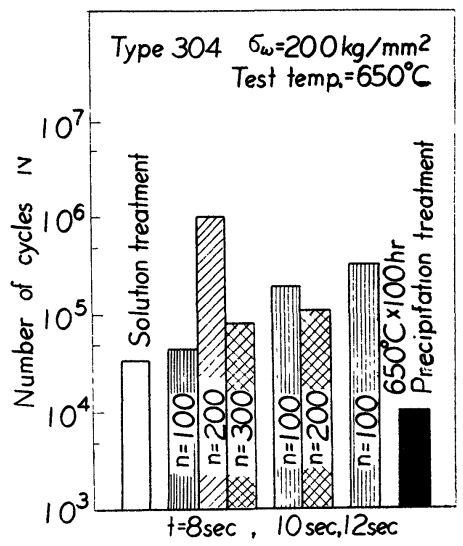

Fig. 6 (a). Effect of various thermal damage on fatigue life at $650^{\circ} \mathrm{C}$. 


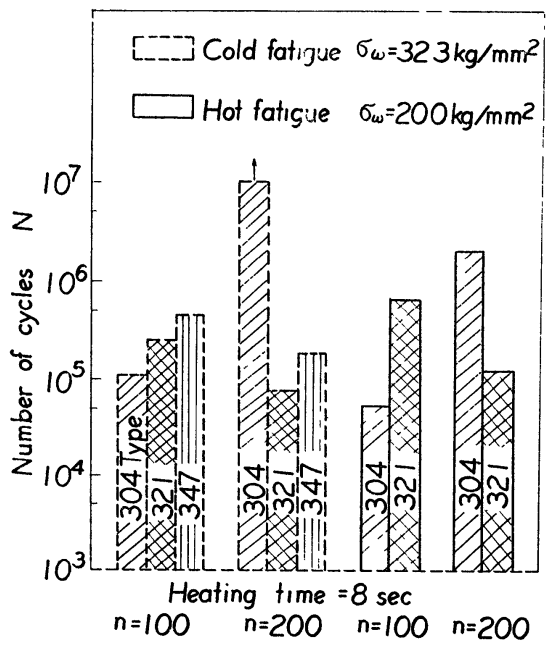

Fig. 6 (b). Effect on composition for fatigue life of thermal dämage.
ある、 $n$ によって疲労寿命はかなり変化することは明 らかで，急熱急冷による熱損傷は疲労寿命で比較する とすべて負損傷となる。なお $650^{\circ} \mathrm{C} \times 100 \mathrm{hr}$ 加熱による 析出処理材は高温耐力が高いにもかかわらず，高温疲 労強度がかたさ変化に比べても意外に低いてとがわか る. Fig. 6 (b)はステンレス鋼の組成の影響について， 常温ならびに高温瘦労寿命試験から調べた結果である。

常温，高温ともに安定化鋼は 8 秒，200 回で，すで に寿命は304鋼より短かくなり，304鋼では逆にかなり 長くなる，乙の変化の要因として，安定化鋼は炭素固 溶量が比較的少ないので熱サイクル中に起とる strain enhanced precipitation の効果が比較的小さいとと, および平均線膨張係数が大きく，熱伝導度も劣るの で熱サイクル中の熱応力が大となり, 試料表面の劣化 が顕著なととが考えられる。

304 鋼熱損傷材の $650^{\circ} \mathrm{C}$ における高温強度をまとめた

Table IV. Relation between tensile strength and fatigue strength in various thermal damages at $650^{\circ} \mathrm{C}$.

\begin{tabular}{|c|c|c|c|c|c|c|c|}
\hline Heat & Cycles & $\begin{array}{c}\text { Proof stress } \\
\sigma_{0.2}^{\prime}\left(\mathrm{kg} / \mathrm{mm}^{2}\right)\end{array}$ & $\begin{array}{c}\text { Tensile strength } \\
\sigma_{\mathrm{B}}{ }^{\prime}\left(\mathrm{kg} / \mathrm{mm}^{2}\right)\end{array}$ & $\begin{array}{l}\text { Endurance limit } \\
\sigma_{\mathrm{W}^{\prime}{ }_{0}\left(\mathrm{~kg} / \mathrm{mm}^{2}\right)}\end{array}$ & $\sigma_{\mathrm{W}^{\prime}}^{\prime}{ }_{0} / \sigma_{0 \cdot 2}^{\prime}$ & $\sigma_{\mathrm{Wo}}^{\prime} / \sigma_{\mathrm{B}}^{\prime}$ & $\begin{array}{l}\text { I.ıfe ratio } \\
\text { N/No }\end{array}$ \\
\hline \multirow{3}{*}{8} & 100 & $\begin{array}{c}12.0 \\
(14.3)\end{array}$ & $\begin{array}{r}34.2 \\
(-8.3)\end{array}$ & $\begin{array}{r}17.0 \\
(-56)\end{array}$ & $\begin{array}{c}1.42 \\
(-17.0)\end{array}$ & $\begin{array}{l}0.50 \\
(4.2)\end{array}$ & 1.31 \\
\hline & 200 & $\begin{array}{l}11.5 \\
(9.5)\end{array}$ & $\begin{array}{r}35.0 \\
(-6.7)\end{array}$ & $\begin{array}{l}190 \\
(56)\end{array}$ & $\begin{array}{r}1.65 \\
(-3.5)\end{array}$ & $\begin{array}{c}0.54 \\
(12.5)\end{array}$ & 27.8 \\
\hline & 300 & 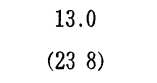 & $\begin{array}{r}37.2 \\
(-0.8)\end{array}$ & $\begin{array}{r}17.6 \\
(-22)\end{array}$ & $\begin{array}{c}1.35 \\
(-21.0)\end{array}$ & $\begin{array}{c}0.47 \\
(-2.1)\end{array}$ & 2.17 \\
\hline \multirow{2}{*}{$\begin{array}{l}10 \\
\sec \end{array}$} & 100 & $\begin{array}{c}128 \\
(219)\end{array}$ & $\begin{array}{l}38.0 \\
(1.4)\end{array}$ & $\begin{array}{l}185 \\
(28)\end{array}$ & $\begin{array}{c}1.44 \\
(-15.8)\end{array}$ & $\begin{array}{l}0.49 \\
(2.1)\end{array}$ & 5.56 \\
\hline & 200 & - & - & $\begin{array}{r}178 \\
(-1.1)\end{array}$ & - & - & 2.92 \\
\hline $\begin{array}{l}12 \\
\text { sec }\end{array}$ & 100 & $\begin{array}{c}14.0 \\
(33.4)\end{array}$ & $\begin{array}{l}40.1 \\
(69)\end{array}$ & $\begin{array}{l}18.2 \\
(1.1)\end{array}$ & $\begin{array}{c}1.30 \\
(-240)\end{array}$ & $\begin{array}{r}0.45 \\
(-6.3)\end{array}$ & 9.17 \\
\hline \multicolumn{2}{|c|}{ Solution treatment } & 105 & 37.5 & 18.0 & 1.71 & 0.48 & - \\
\hline \multicolumn{2}{|c|}{$\begin{array}{l}650^{\circ} \mathrm{C} \times 100 \mathrm{hr} \\
\text { Precipitation }\end{array}$} & $\begin{array}{l}15.8 \\
(50.5)\end{array}$ & $\begin{array}{c}33.1 \\
(-12.7)\end{array}$ & - & - & - & 0.28 \\
\hline
\end{tabular}

結果，Table IV のようになる，常温での耐久限は常 温引張強度によく対応した変化を示したが, 高温疲労 強度はその温度にわける引張強度とほとんど対応せず， 熱損傷によってかなり変わるてとがわかる，さらに $\sigma_{w o} / \sigma_{0.2}$ が1より大きくなる特徴がある.

\section{3 -3 かたさ特性}

Fig. 7 は直径 $8 \mathrm{~mm}$ の試料に 8 秒, 加熱による熱サ イクルのみを500回まで絽り返した301鋼の直径方向の かたさ分布曲線である. $n=10$ 回の比較的少ない場 合 でも $H v \cong 20$ 程度硬化し, 表面部はさらに硬化する. しかし, $n=100 \sim 200$ 回の試料では図のように表面か ら内部へ約 $3 \mathrm{~mm}$ の範囲にわたる硬化帯が認められ，

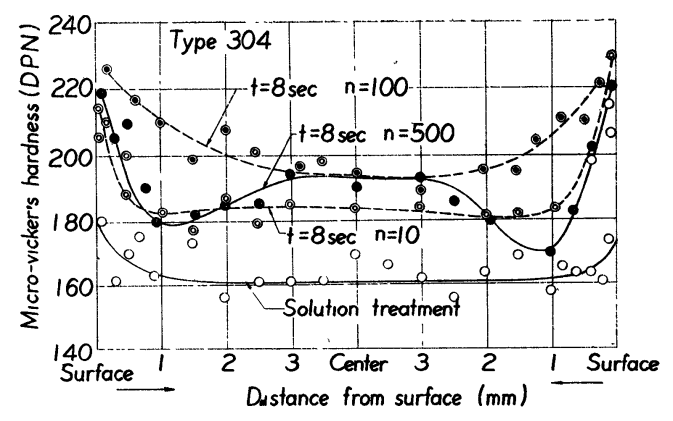

Fig. 7. Changes in hardness distribution caused by thermal damage. 


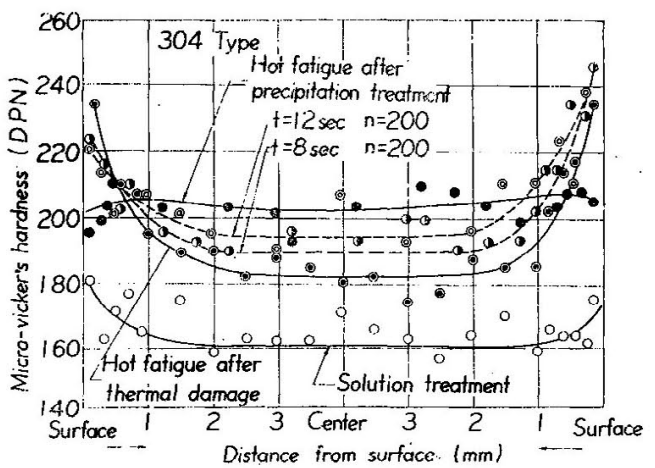

Fig. 8. Changes in hardness distribution caused by thermal damage and hot fatigue test.

炭素鋼に高周波許入れしたかたさ分布とほぼ闹じ変

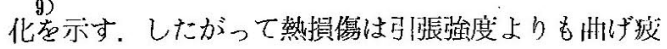

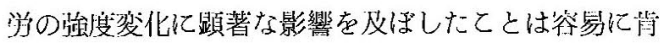

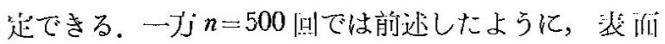
には山周方向に巨視的き裂が発生し，表睢より約 0.5

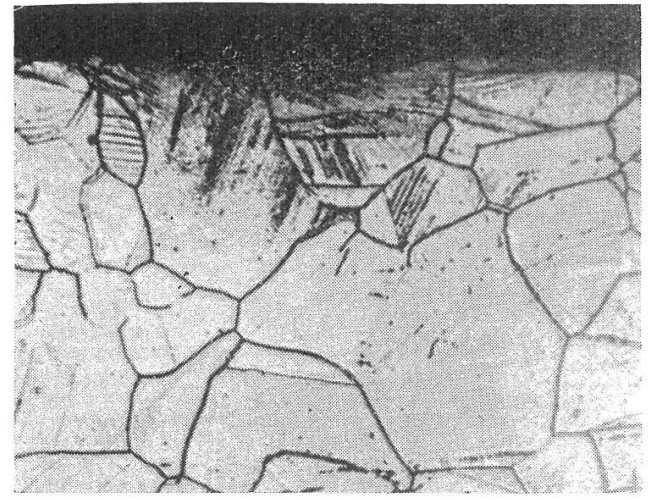

(a) Thermal damage

$$
\begin{aligned}
& t=8 \mathrm{sec} \\
& n=100
\end{aligned}
$$

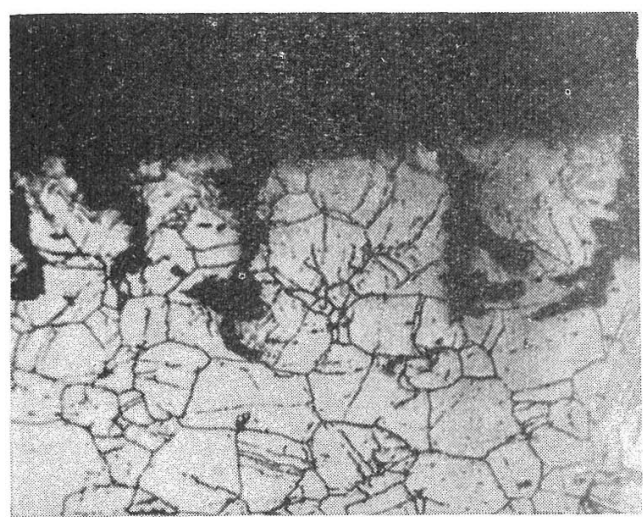

(c) $t=8 \mathrm{sec}$

$(\times 200)$

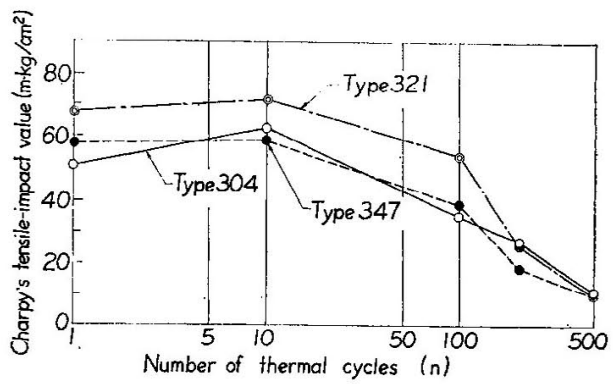

Fig. 9. Changes in tensile impact values caused by thermal cycles of austenitic stainless steels.

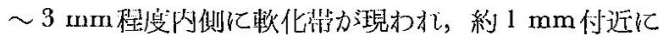
招いて最低かたさを示した。また ま21，347銅では $n=$ 200回で，すでにき裂の発生か涊められ，Fig. 6 のよう に揣度但下在生ず。

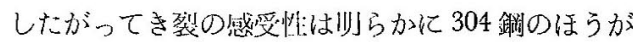
小さいことが壮明した。

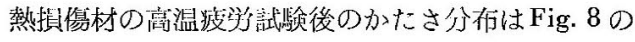
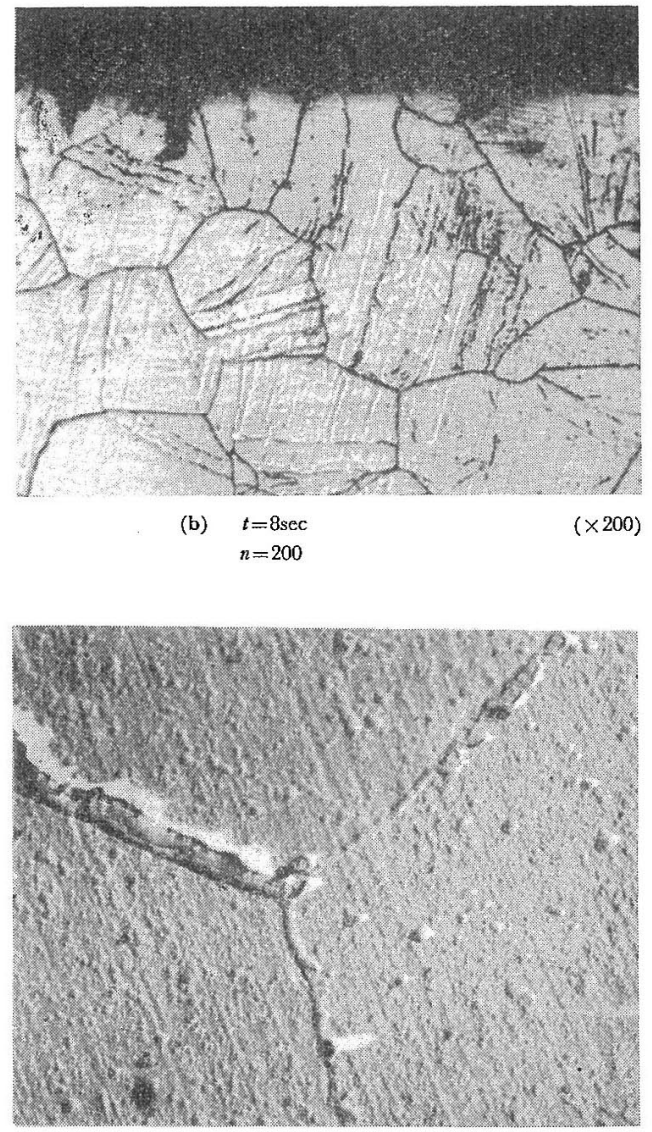

(d) Detail of (a)

$(\times 4000)$

Fig. 10. Microstructures of various thermal damage caused by repeated heating and cooling. 
ようである，損傷直後と試験後のかたさには変化は認 められるが，分布の傾向忙著しく変わらないととがわ

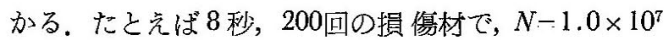
(約48hr)で破断しなかった試料の表面かたさは試鈋前 後に㧊いてほとんど变わらないが，疲学後，中心部で は軟化の傾向が現われる。乙れは析出粒子の成辰に上

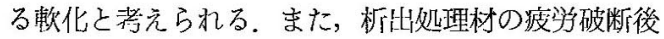
のかたさは溶体化迈理材に比して $H_{v}=40 \sim 50$ 程度硬 化しているが，中心部と表面部の硬度差はほとんどな く，全面にわたってほぼ一様のかたさを示す。しかも， 表面の最高办たさは他の損傷材よりもかなり低い。し たがって析出处理材は高温酎力の高い㓶合比曲げ疲学
強度の低いことが理解できる。

急熱急冷の繰り返しによる硬化の最大要因の一つは, 炎化物などの Strain enhanced precipitation hardening で，析出物は主として粒内のすべり線，転位の 応力場にでる。乙れは後で示す組織变化で実徰してい

る. (Fig. 10，11参照)

\section{3 - 4 衝擊特性}

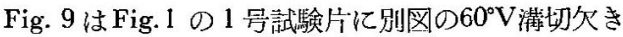
を付け，1 500 回の熱損傷材の常温におけるシャル ピー引張衝撃值の変化である。図のように $n$ の少ない ときはオーステナイト系特有の高い勒性を示すが， n $=100$ 回ですでに脆化し贻め，n=200〜500回では，か

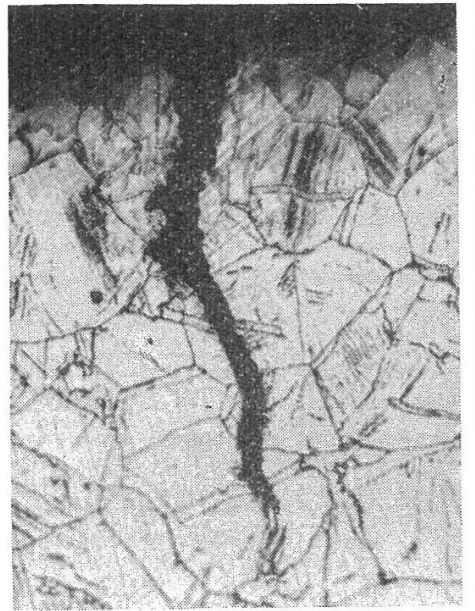

(a) Type 304

$R$ T. $\left.N=4.6 \times 10^{6}\right)$

after $t=8 \mathrm{sec}, n=500$.

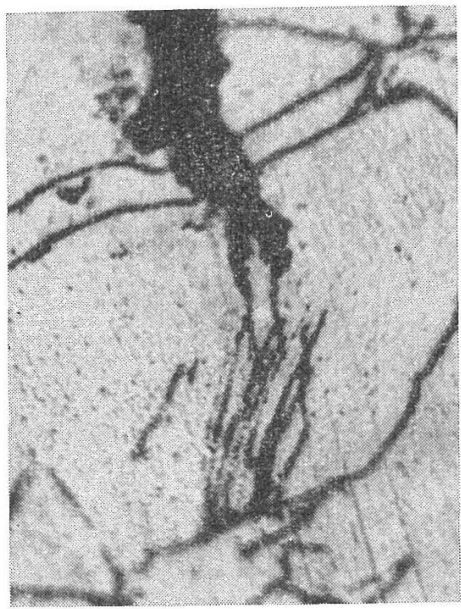

(d)

l)etail of (a) at crack pointed end.

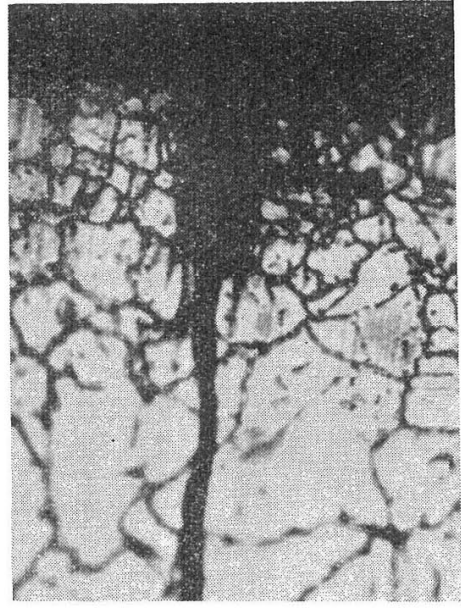

(b) Type 304 $650^{\circ} \mathrm{C}$ fatigue test $\left(\sigma=23.0 \mathrm{~kg} / \mathrm{mm}^{2}\right.$ $\left.N=1.0 \times 10^{4}\right)$

after $t=12 \mathrm{sec}, n-100$

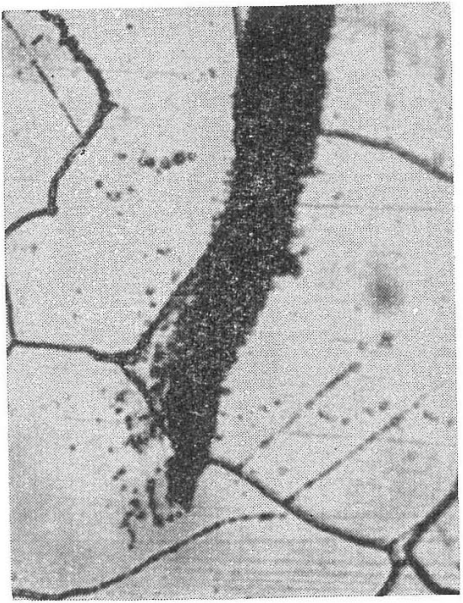

(e) Type 304

$650^{\circ} \mathrm{C}$ fatigue test $\left(\sigma=20.0 \mathrm{~kg} / \mathrm{mm}^{2}\right.$ $\left.N=1.0 \times 10^{5}\right)$

after $t=8 \mathrm{sec}, n=300$

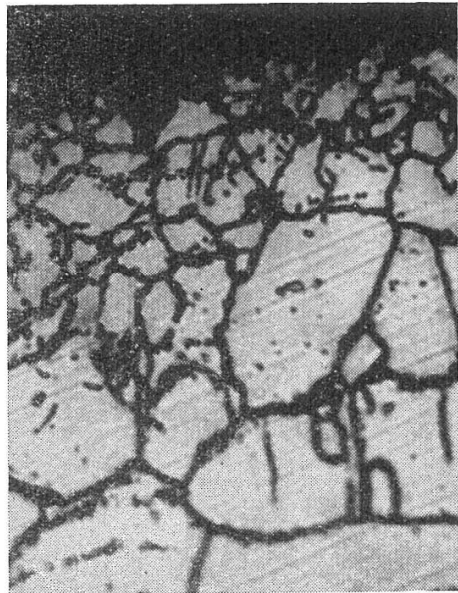

(c) Type 301

$(\times 800)$ Other surface of (b)

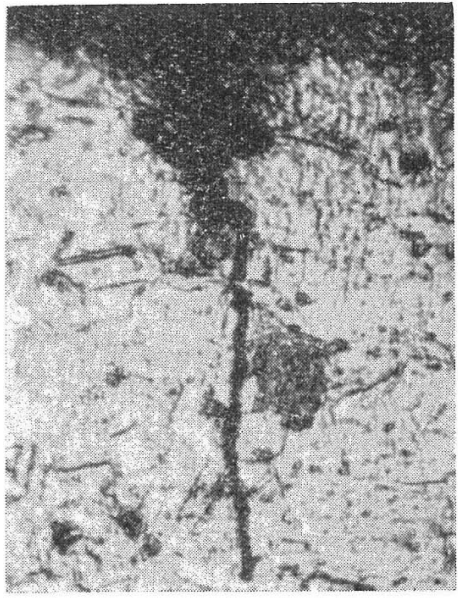

(f) Type $=347$

R.T. fatigue test $\left(\sigma=32.3 \mathrm{~kg} / \mathrm{mm}^{2}\right.$ $\left.N=2.1 \times 10^{\mathrm{s}}\right)$

after $t=8$ sec, $n=200$

Fig. 11. Microstructures after fatigue test of thermal damaged stainless steels at room temperature and $650^{\circ} \mathrm{C}$. 
なり著しく脆化することが認められる。ととに安定化 銅の脆化率が大きく，急熱急冷による熱き裂の感受性 の大きいてとが明らかである、このように熱損傷は衝 撃抵抗に対してすべて損賃を与え，かなり劣化させる ので，他の強度の变化が少なくても鹤性を必琶とする 場合，充分なる注意を要する。

\section{$3 \cdot 5$ 組織特性}

3・5・1 顕微鏡組織の変化 熱損鹪を受けたス テンレス鋼の組織変化は局部的にかなり著しい恋化が ある。組織と強度変化との関係について顕微鏡を利用 して調査した。

Fig.10は30鋼に8 秒，加熱をそれぞれ100,200およ び 500 回の熱損傷のみを加えた場合の表面部の組織で ある: 袁面の結晶粒界わよび粒内のすべり帯には若干 の析出物が認められる。また, 粒界に沿うてヒートチ エッキングも現われている、ととに， $n=500$ 回の損稘 村では(c)のように平均深さ100んで,き裂先端が繰り返 し加熱による酸化現象のため丸味を帯びたものとなる，

(d)は(c)の表面部分を 2 段レプリカ法によった電子顕 微鏡組織である. 8 秒, 500 回の熱サイクルで, 㬌積 加熱時間もかなりに達しているため，粒界および粒内 に析出物が析出している。ととに粒界の一部には凝集 成長した大きな析出物が確認できる。

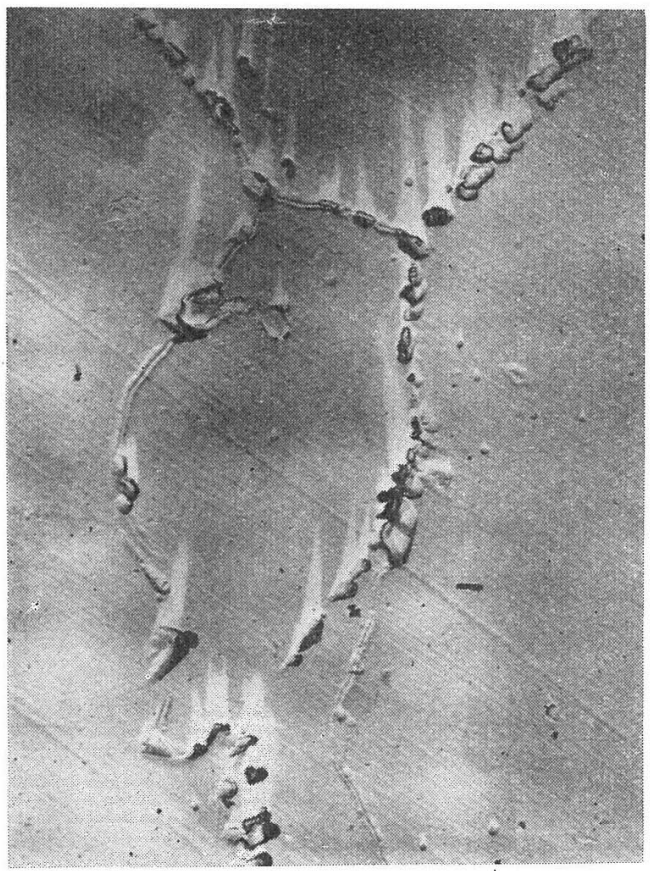

(a) Type 304

$(\times 500)$

650 'C fatigue test $\left(\sigma=18.2 \mathrm{~kg} / \mathrm{mm}^{2}\right.$, $N=2.6 \times 10^{6}$ ) after $t=12 \mathrm{sec}, n=100$.
Fig. 11は304および347銅の熱損傷材をそれぞれの条 件で常温または疲学試験後, 破断面付近に認められた き裂の例である。(a)〜(e)は 301鋼で，たとえ発生が粒 界であろらと，常温わよび高温疲学によるき裂はすべ て粒内破断の型式を示す。(d)(e)は疲学き裂の先端部の 抬大写真で，き裂の伝播が粒内析出物によって阻止せ られ，停留しているものを示す（f）は 347 鋼のヒート チェッキングと，その先端を発生源とした疲学き裂か らなるき裂である。垒損傷材の疲労き裂は(b)かるわ かるように試験温度，組成にほとんど無関係で同じ機 構のもとにき裂の発生が行なわれるようである。また (d)就よ゙゙(c)で明らかなように表面㞗の結晶粒度はきわ めて微細化され，高温疲労後の試料において特に顕著 である，てのように，熱サイクルは試料表面部の結晶 粒度を微細化する。また，確認は困難であったが，副 結晶粒が作られ，高温疲学中にこの副結晶粒界に岸化 物が析出し，結晶粒がさらに要細化されたとみなされ 3.

光学顕微鏡では析出過程の詳細について不明な点も 多いので, 熱損傷材の高温疲労試験後の試料について さらに 2 段レプリカ法によって電子顕微鏡でも检鏡し た. Fig.12はその組織の一例で，(a)は $N=2.6 \times 10^{6}$ (約 I3hr) で破断した試料であり，(b)は $N=1.0 \times 10^{7}$ (約48

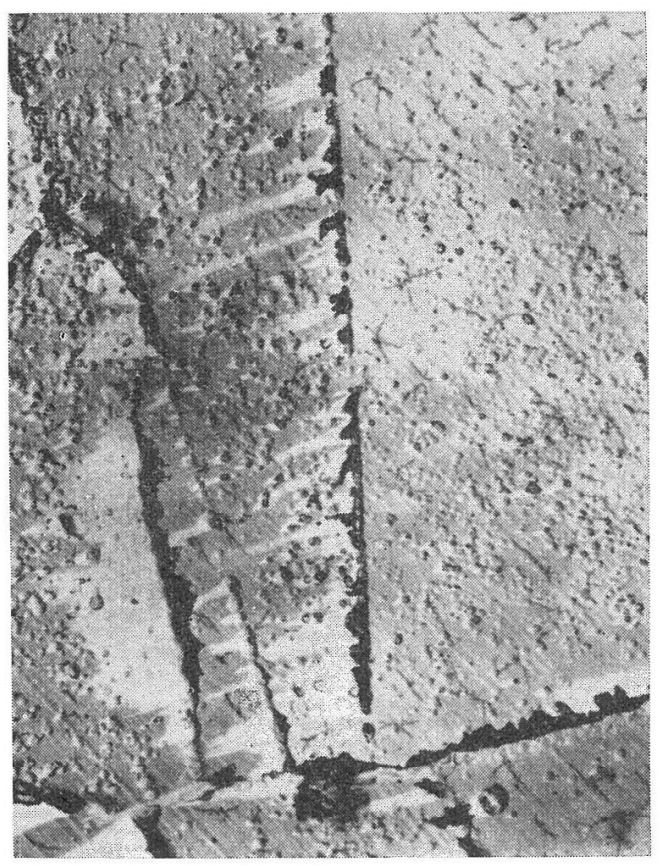

$\begin{array}{cc}\text { ( b ) Type } 304 & (\times 5000) \\ 650^{\circ} \mathrm{C} \text { fatigue test }\left(\sigma=19.0 \mathrm{~kg} / \mathrm{mm}^{2},\right. \\ \left.N=1.0 \times 10^{7}\right) \text { after } t=8 \mathrm{sec}, n=200 .\end{array}$

Fig. 12. Electron microstructures after hot fatigue test for thermal damaged at $650^{\circ} \mathrm{C}$. 
hr) 繰り返し，なお，破断しなかった試料の組織であ る. (a)の粒界や副結晶界にはかなりの析出物が鎖状に 析出しているが，粒内にはほとんご疑集析出物は認め られない，しかるに，(b)では粒界，双晶帯はもち論の こと，粒内に微細析出物が全面にわたって析出してい る.これが Strain enhanced precipitation である. 注意深く観察すると，乙の微細析出物はある結晶面に 平行に並んでおり，熱サイクルによる熱応力のために 起とった塑性ひずみによって強制析出したものであろ う.また，強度に対して $n$ の適当なときは，加熱時間 が比較的短いので, 析出核が臨界大きさに達した後は 核成長がほとんど起てらないであろうから転位を $\mathrm{p}$ in し，新しい転位の障壁となるが，転位の発生源となら ないであろう。しかし， $n$ が大になれば臨界大きさの 析出核が成長し, 不整合粒子となれば強度は低下する。 さらに nが増大すればき裂がはいり，損傷材となる，

3・5 - 2 X線回析試験 熱損傷ならびに高温疲 労試験中における表面部の変化をX線ディフラクトメ 一タでも調べてみた，X線ビームは図のように表面に
直接当てて得た回析像の一部が Fig. 13である. (a)は304 鋼に 8 秒 200 回の熱サイクルのみを加えた場合で，熱 損傷によって表面硬化は認められたが，X線回析像に は溶体化処理材とほとんど変化はない．(b)は(a)を高温 疲労破断させた試料であるが，てれも大した変化はみ られない.(c)はFig. 12(b)で示した同一試料で耐久限に 達した試料の回析像である. この反射角の範囲内では， (a)(b)ともにr (111) からの反射のみで，完全オーステ ナイトであるととがわかる。しかし(c)ではわずかであ るが $\boldsymbol{( 1 1 0 )}$ からの反射が喼められ，フェライト生成 量は約 $1 \%$ である。 ての現象の詳細については不明で あるが，熱サイクル中における Strain enhanced precipitation のためにオーステナイト母体の固溶炭 素量の低下によって，オーステナイトの安定性が低下 し, $650^{\circ} \mathrm{C}$ 疲労試験中ならびに冷却後にわいて, 局部 的ではあるが， $\gamma \rightarrow \alpha$ 変態が起てったものである.ま た，てれは strain enhanced precipitation が起てっ たととを実証していると言えよう。

以上の結果から急熱急冷による熱損傷材は普通の析

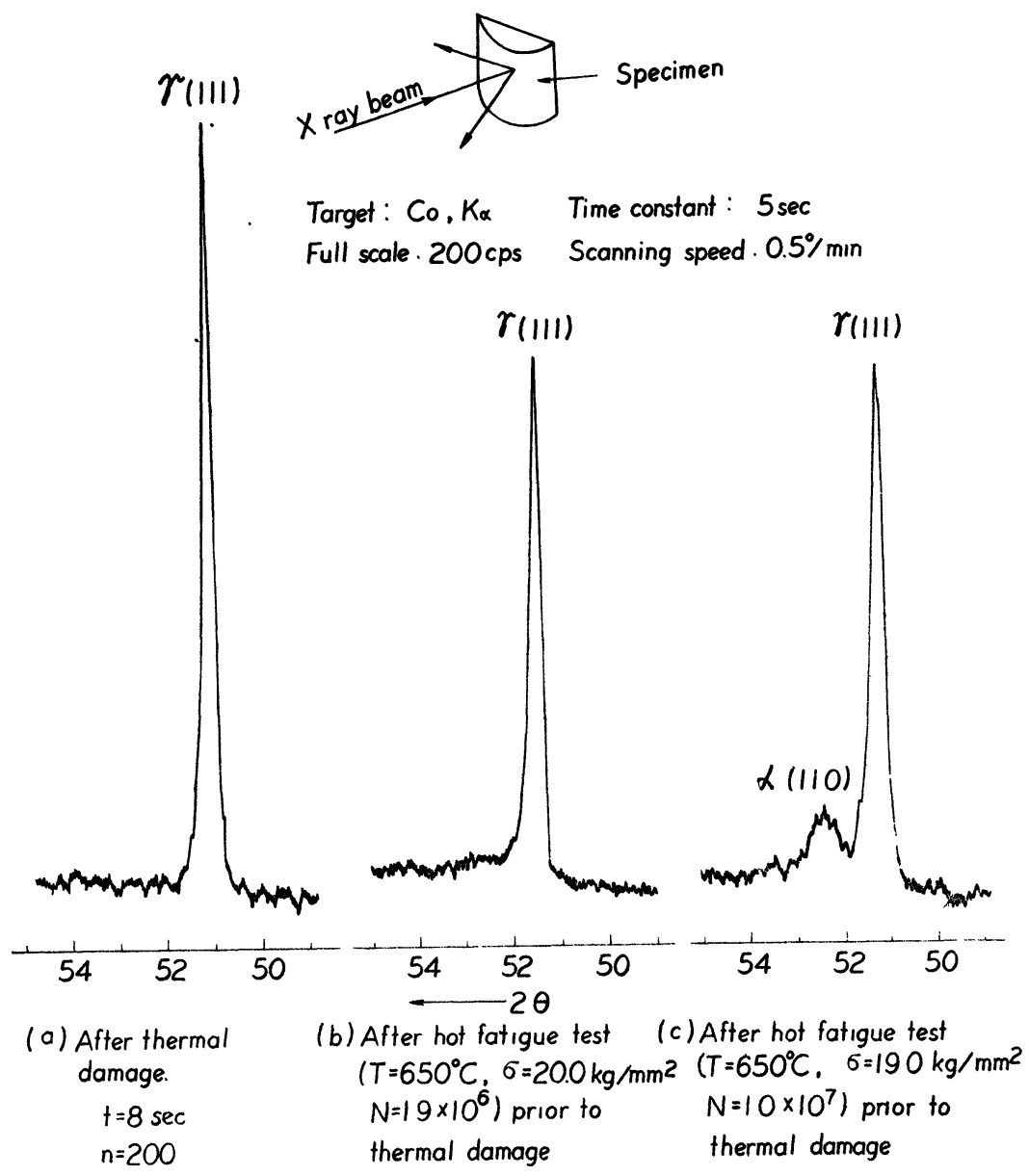

Fig. 13. X-ray diffraction patterns after thermal damages and hct fatigue test of with that type 304 specimen. 
出妈理材とかなり異なった機械的強度の変化を示し， 組織的にもかなり相違のあるととがわかった。すなわ ち加熱による析出は主として粒界あるいは副結晶粒界 に析出するのに反して, 熱サイクルの場合は表面部に 著しい Strain enhanced precipitation が起とり,し かも析出粒子は著しく成長しない.

\section{4 結言}

以上18-8系ステンレス鋼の熱損傷材の常温ならびに 高温における機械的性質の変化について実験した結果， 急熱急冷の熱サイクルは必ずしも材料の強度を害する ものではないてとがわかり，次のような結論を得た。

（1）ステンレス鋼に急熱急冷の繰り返しによる熱損 傷を加えると, 表面部は熱応力によるすべりのため, いわゆる Strain enhanced precipitation が起とり, かなり硬化される。この熱損傷は引張特性よりも曲げ 疲労特性に対して著しい影響を及ぼす。

（2）急熱急冷の累積熱損傷が有効加熱量のときには 負損傷を与え，常温ならびに高温強度は上昇する。し かし，ある一定量を越えると析出粒子の成長によって 強度は低下する。乙の影響は高温強度に対するよりも 常温強度に対して顕著である.

（3）熱損傷による析出は普通の加熱による析出と異 なり，粒内全面にわたって微細析出物が析出し，転位 の運動に対する抵抗力を増加させる。しかし，熱損傷 で生成されたき裂は，その後のき裂の発生源となる。
（4）急熱急冷の繰り返しに対する耐熱性は 304 鋼の ほうが321，347鋼より高い.

本研究に対し，実験用試料の提供を載いた日本金属 工業株式会社水野常務および塚本工場辰に深く感謝の 意を表わします。

(炤和 39 年 5 月 15 日, 日本材料学会第13期総会講寅会にて講寅)

\section{参考文 献}

1）渡辺十郎，日本製鋼技報，6，463（1961）。

2) 長谷川正義, “ステンレス鋼便覧”278(1960) 日刊 工業.

3）泉久司，“ステンレス鋼の高温強度特性に関する 研究” 1 ～ 3 章 (1961) 学位請求論文.

4) 篠田軍治, 佐野忠雄, 桜井忠一, 川崎正, 泉久司, 金属学会誌, 23, 643 (1959).

5) Cottrell, A.H., Phil. Mag., 44, 829 (1953).

6) 藤原達雄, 金属学会報, 1, 177 (1962).

7) Northcotl, L., and H.G. Baron, J. Iron \& Steel Inst., 184, 385, (1956).

8）横堀武夫，“材料強度学” 152, (1955) 技報堂.

9) 中村宏, 甘粕達雄, 機械学会論文集, 26, 95(19 60).

10）川崎正，篠田軍治，金属学会誌，22，489 (1958).

11) Gina, B.J., Iron \& Steel Inst., 179, 230(1955). 